\title{
Results of Selection Studies of Alfalfa Based on Inbred
}

\section{Lines}

\author{
Meirman Galiolla, Kenenbayev Serik, Yerzhanova Sakysh, Abayev Serik and Toktarbekova Saltanat \\ Kazakh Scientific Research Institute of Agriculture and Plant Growing, Almalybak, Almaty Region, 040909, Kazakhstan
}

\begin{abstract}
The collection of alfalfa in the context of ecology-geographical groups was studied, consisting of 1,078 samples, including 985 samples of the cultivated species-M. sativa L. and M. varia Mart., and 93 samples for other wild species. Highly productive samples are allocated in the three-year cycle of using the grass stand in the haymaking regime. Individual genotypes of isolated samples are used for selection of inbred lines required for the formation of synthetic varieties. Inbred lines were created by forced self-pollination on genotypes with signs of self-fertility. Methodical experiments established the efficiency of bringing inbred lines to generations $\mathrm{J}_{2}$ and $\mathrm{J}_{3}$. In this case, the overall combinational ability reaches a potential value, and further incubation outside of $\mathrm{J}_{2}$ and $\mathrm{J}_{3}$ does not significantly affect its value. With the selection of the best inbred lines in $\mathrm{J}_{2}$ and $\mathrm{J}_{3}$, the lucerne varieties: Kokorai, Osimtal and Kokbalausa, which are protected by patents and author's certificates, have been created in accordance with the general combination ability and their inclusion in the structure of synthetic varieties.
\end{abstract}

Key words: Inbred lines, general combination ability (GCA), synthetic grade, yield of green mass.

\section{Introduction}

The diversity of the initial forms of alfalfa, especially local varieties, generated by factors of formation form and differentiation, is increased due to a number of sharply separated geographic regions, each of which has its own set of varieties. In modern agriculture, alfalfa is cultivated on all continents of the globe, and due to soil-climatic factors, as well as natural and artificial selection, its gene pool is continuously replenished with local and selection varieties.

The genetic composition of the variety and species potential of alfalfa is directly related to the habitat ecology, cultivation methods and use. In nature, localization of signs and properties takes place depending on the ecology-geographical regions of origin of the samples.

At present, based on the generalization of the study results of the extensive world collection of alfalfa from the All-Russian Research Institute of Plant Industry named after N.I. Vavilov (A-RRIPI), the maps of the

Corresponding author: Yerzhanova Sakysh, associate professor, research field: genetic resource of plant (forage crops). localization of the genoplasm of the most important signs and properties of perennial alfalfa species of subgenus Falcago are compiled on the centers of origin of plants $[1,2]$.

Hence, study and selection of the source material for alfalfa should take into account ecological effect in order to make fuller use of each ecotype in the different eco-geographical group. This approach greatly facilitates the search for the necessary attributes and properties among the huge variety of alfalfa.

The breeding of synthetic varieties is a logical continuation of the method of selection of complex hybrid populations. Improvement of the latter concerns the selection of the initial forms through the indicator of the overall combinational ability as a genetic attribute providing a high and stable effect of heterosis in populations. Difference in the method of breeding synthetic varieties from other methods, including the selection of complex hybrid populations, is in particular, the establishment of the value of general combination ability (GCA) and the preliminary selection of the original forms on this basis before merging them into new synthetics. Identification of genotypes by GCA is the main task of selection of synthetic varieties of alfalfa. As initial genotypes, they 
can use different source of materials (clones, families, biotypes, whole populations, inbred lines). It is important that the components of synthetics were of unrelated origin, since the closely related material reduces their productivity [3].

A positive property of synthetics is their high plasticity, which provides enhanced resistance to unfavorable environmental conditions and the possibility of long-term use as a self-reproducing population with a pronounced effect of heterosis. The creation of synthetic varieties at this stage in the development of alfalfa breeding is considered the most acceptable way of using heterosis in the theoretical, practical and organizational aspects. With its help, are created varieties that are resistant to biotic and abiotic factors of the environment, with high quality indicators. For fodder grasses, it is an indispensable method of creating forms that combine vegetative and reproductive data.

Selection of alfalfa using inbred lines is a longer process compared to traditional, based on heterozygous clones. This is due to the creation and allocation of the combination of valuable lines. If they meet the selection requirements (phenotype uniformity, the smallest inbred depression or high combinational ability), then its effectiveness can be dramatically increased.

In the process of self-pollination, since many genes become homozygous, there is the possibility of rapid elimination of forms with negative traits and the allocation of valuable lines for conducting heterotic selection on an inbred basis. However, the problems of creating inbred lines of alfalfa and their use for the synthesis of new populations of synthetic varieties have not been adequately studied. The decisive factor for success in this case is the formation of an extensive collection of lines, expanding the possibilities of selection and genetic research [4].

Experimental data on the creation and use of inbred lines of alfalfa are limited. Nevertheless, Rotili and Zannone [5] testified the advisability of bringing the inbred line up to the second and third generations $\left(\mathrm{J}_{2}\right.$ and $J_{3}$ ). This research is devoted to the selection processes of alfalfa to isolate the valuable samples and on their basis create inbred lines for inclusion in newly synthesized populations (varieties).

\section{Materials and Methods}

This study investigated the genetic resources of two alfalfa species-M. sativa $L$. and M. varia Mart., represented by 985 specimens with a coverage of 32 eco-geographical groups according to the classification of A-RRIPI. M. falcate L. is represented by 58 samples from seven eco-geographical groups. Wild species included 12 samples for M. coerulea Less., three samples for M. hemicycla Gross., 10 samples for M. polychroa Sinsk., two samples for each of M. tianschanica Vass., M. glutinosa Bieb., M. agropyretorum Vass. and M. trautvetteri Sumn., one sample for each of M. glandulosa David and M. lavrenko Vass..

The study and evaluation of the gene pool was mainly carried out in a collection nursery using A-RRIPI [6] and All-Russian Research Institute of Forages (A-RRIF) [7] method. As a standard variety, Semirechinskaya is used.

The inbred lines $J_{2}$ and $J_{3}$, derived from the Semirechinskaya and Dawson clones, served as the initial materials. These lines were included in the topcross scheme to obtain $F_{1}$. Crosses were carried out according to the standard method, resulting in 48 direct hybrid combinations. The testers were clones isolated from the varieties Semirechinskaya local, Iolotan 1763 and Local from China (k-32860). For self-pollination, plants from the group of biotypes that most correspond to the requirements of intensive forage production were selected. The whole plant or individual brushes and shoots with inflorescences were placed under gauze insulators in order to protect the flowers from cross pollination by insects. Under the conditions of the greenhouse, the work was carried out without prior isolation, and the flowers were 
opened by hand.

Inbred lines in the process of crossing up to $\mathrm{J}_{7}$ were selected for self-fertility. From each generation of inbred lines, 30 plants were analyzed for quantitative traits. The lines were compared with each other and with the offspring of the original plant from free dusting.

For a complete description of the samples, a unified Countries Ekonimic Interactions (CEI) classifier was used for the types of crops. The experimental material was statistically processed according to Dospekhov [8] using a personal computer and a package of applied programs. The estimation of GCA was carried out according to the method of Savchenko [9] for topcross.

\section{Results and Discussion}

M. sativa L. and M. varia Mart. are widely spread in culture in all agricultural regions of the world. They differ sharply in productivity from other known species of alfalfa. Depending on the nature of use, the direction of artificial and natural selection, and the complex caused by ecological conditions, different varieties were formed. In this regard, the results of studies on the collection are presented in the context of ecological-geographic groups with a general characteristic and the distribution of the most valuable samples for economically valuable traits and biological properties.

Through long-term studies on specimen collected from lucerne sowed at 2-4 slopes per hay in nurseries each year for 3-4 years, the high-yielding samples were identified.

As can be seen from Table 1, a total of two samples of wild-growing species exceeded the productivity of the standard variety (Semirechye local) of more than $20 \%, 49$ samples from $6 \%$ to $20 \%, 85$ samples at the standard level, while the productivity of 754 samples was below the standard.

Among the 47 highly productive samples of $M$. sativa L. and M. varia Mart., samples with the productivity exceeding the standard of Semirechinskaya local variety by more than $20 \%$, are from:

(1) Plain-Turkestan eco-geographical group: Tajikistan local (k-1060, k-1477 and k-1152), Milyutinskaya 1774 (k-26596) and Mestnaya (k-1164) from Uzbekistan, Uzgen improved (k-2775) from Kyrgyzstan;

(2) Semirechye eco-geography group: Kazakhstan local (k-6292, k-6293, k-6401, k-1276, k-6401, k-6293 and k-1839), Markinskaya (k-1720) and Frunzenskaya 9 (k-2777) from Kyrgyzstan;

(3) South European eco-geographical group: Flamande (k-6926), Poiton (k-6621) and Provencal (k-22868) from France, Sabina (k-5356) from Italy, Albania local (k-1269) and Bulgaria local (k-24134);

(4) Western European eco-geographical group: Germany local (k-887) and Serbia Local (k-39934);

Table 1 Level of yield of lucerne samples in the context of different eco-geographical groups.

\begin{tabular}{|c|c|c|c|c|c|}
\hline \multirow[b]{2}{*}{ Eco-geographical group } & \multirow{2}{*}{$\begin{array}{l}\text { No. of studied } \\
\text { samples }\end{array}$} & \multicolumn{4}{|c|}{ In comparison with the standard variety } \\
\hline & & $\begin{array}{l}\text { Exceeding for } \\
\text { more than } 20 \%\end{array}$ & $\begin{array}{l}\text { Exceeding for } \\
6 \%-20 \%\end{array}$ & $\begin{array}{l}\text { In the level of } \\
95 \%-105 \%\end{array}$ & Inferior \\
\hline \multicolumn{6}{|c|}{ M. sativa L. and M. varia Mart. } \\
\hline Khiva & 11 & - & 1 & - & 10 \\
\hline Plain-Turkestan & 85 & 6 & 10 & 16 & 53 \\
\hline Semirechenskaya & 66 & 9 & 6 & 12 & 39 \\
\hline Turkmen & 21 & 2 & 3 & 2 & 14 \\
\hline North Kazakhstan & 17 & 1 & 4 & 4 & 8 \\
\hline Chinese plain & 18 & 1 & 2 & 3 & 12 \\
\hline Chinese footh & 9 & 1 & 1 & 2 & 5 \\
\hline Kashgar & 10 & - & 1 & 3 & 6 \\
\hline
\end{tabular}


(Table 1 continued)

\begin{tabular}{|c|c|c|c|c|c|}
\hline \multirow[b]{2}{*}{ Eco-geographical group } & \multirow{2}{*}{$\begin{array}{l}\text { No. of studied } \\
\text { samples }\end{array}$} & \multicolumn{4}{|c|}{ In comparison with the standard variety } \\
\hline & & $\begin{array}{l}\text { Exceeding for } \\
\text { more than } 20 \%\end{array}$ & $\begin{array}{l}\text { Exceeding for } \\
6 \%-20 \%\end{array}$ & $\begin{array}{l}\text { In the level of } \\
95 \%-105 \%\end{array}$ & Inferior \\
\hline Kandahar-Kabul & 11 & - & - & 2 & 9 \\
\hline The Transcaucasian plain & 38 & 2 & 2 & 10 & 24 \\
\hline Minor Asoam & 9 & - & 3 & 1 & 5 \\
\hline South European & 136 & 6 & 12 & 32 & 86 \\
\hline West European & 80 & 2 & 7 & 24 & 47 \\
\hline Ukrainian & 59 & 1 & 6 & 9 & 43 \\
\hline North Caucasian & 50 & 2 & 3 & 4 & 41 \\
\hline South-Eastern & 11 & - & 1 & 1 & 9 \\
\hline North-Eastern & 17 & 2 & 2 & 3 & 10 \\
\hline North-Western & 7 & - & - & - & 7 \\
\hline Middle Russian & 19 & 1 & 1 & 1 & 16 \\
\hline West Siberian & 21 & 1 & 1 & 1 & 18 \\
\hline East Siberian & 15 & - & 1 & - & 14 \\
\hline North American & 95 & 1 & 4 & 17 & 73 \\
\hline Canadian & 8 & - & - & 2 & 6 \\
\hline Chile-Peruvian & 28 & - & 2 & 5 & 21 \\
\hline Mexico-Brazilian & 25 & - & 2 & 3 & 20 \\
\hline Argentinian & 9 & - & - & 3 & 6 \\
\hline Indian & 28 & 2 & 4 & 3 & 19 \\
\hline North African & 42 & 4 & 3 & 10 & 25 \\
\hline Mesopotamian & 9 & 1 & - & 3 & 5 \\
\hline Syrian & 7 & 1 & 2 & - & 4 \\
\hline Yemeni & 7 & - & 1 & 2 & 4 \\
\hline Ladak & 17 & 1 & - & 1 & 15 \\
\hline Total & 985 & 47 & 85 & 179 & 674 \\
\hline \multicolumn{6}{|c|}{ Eco-types of yellow lucerne (M. falcate L.) } \\
\hline Ukrainian Steppe & 3 & - & - & - & 3 \\
\hline North Caucasian & 16 & 1 & - & - & 15 \\
\hline Salsk Steppe & 4 & - & - & - & 4 \\
\hline South-Eastern & 16 & - & - & 2 & 14 \\
\hline North Russian & 1 & - & - & - & 1 \\
\hline West Siberian & 7 & - & - & - & 7 \\
\hline East Kazakhstani & 11 & - & - & - & 11 \\
\hline Total & 58 & 1 & - & 2 & 55 \\
\hline \multicolumn{6}{|l|}{ Other wild Lucerne } \\
\hline Lucerne blue (M. coerulea Less.) & 12 & - & - & - & 12 \\
\hline Semicyclic (M. hemicycle Gross.) & 3 & - & - & 1 & 2 \\
\hline Adhesive (M. glutinosa Bieb.) & 2 & - & - & - & 2 \\
\hline $\begin{array}{l}\text { Multicolored (Subsp. M. polychroa } \\
\text { Sinsk.) }\end{array}$ & 10 & 1 & - & 2 & 7 \\
\hline Tyanshanskaya (M. tianshanica Vass.) & 2 & - & - & 1 & 1 \\
\hline Lavrenko (M. lavrenko Vass.) & 1 & - & - & 1 & - \\
\hline Crisp (M. agropyretorum Vass.) & 2 & - & - & 2 & - \\
\hline Traufetter (M. trautvetteri Sumn.) & 2 & - & - & 2 & - \\
\hline Glandular (M. glandulosa David) & 1 & - & - & - & 1 \\
\hline Total & 35 & 1 & - & 9 & 25 \\
\hline Total & 1,078 & 49 & 85 & 190 & 754 \\
\hline
\end{tabular}


(5) Turkmen eco-geographical group: Mary (k-6435) and Turkmenistan local (k-6446) from Turkmenistan;

(6) North Kazakhstan eco-geographical group: Karabalykskaya 18 from Kazakhstan;

(7) Chinese plain and foothill eco-geographical groups: local (to-32860 and to-32861) from China;

(8) Transcaucasian plain eco-geography group: Armenia local (to-19974) and Azerbaijan local (to-29012);

(9) Ukrainian blue-hybrid ecoy-geographical group: Kiev (to-21787) from Ukraine;

(10) North Caucasian syne-hybrid eco-geographical group: Slavic local hybrid (to-29006) from Russia;

(11) Northeastern blue-hybrid eco-geographical group: Urzhumskaya local (k-32092) and Sinhybrid (k-32097) from Russia;

(12) Central Russian syne-hybrid eco-geographical group: Marusinskaya 425 from Russia;

(13) West Siberian syne-hybrid eco-geographical group: Omsk 192 from Russia;

(14) North American syne-hybrid eco-geographical group: Cossack (to-20052) from USA;

(15) Indian eco-geographical group: to-21369 and to-21370 from India;

(16) North African eco-geographical group: k-3190, k-33675, k-22380 and k-7305 from Egypt;

(17) Mesopotamian eco-geographical group: k-7221 from Irak;

(18) Syrian eco-geographical group: to-19938 from Syria;

(19) Ladaki eco-geography group: Tibetan (to-1825) from Kazakhstan.

In the context of eco-geographical groups of cultivated species $M$. sativa L. and $M$. varia Mart., a set of economically valuable features was evaluated due to the following reasons:

(1) Samples from the Chinese plain eco-geographical group differ, for early ripening, rapid spring growth and post-mowing regrowth. In the most early-maturing specimens, flowering in the first cut of k-32860 and k-32861 occurs on the 51-55d from the spring regrowth;

(2) Samples from the Canadian blue-mottled hybrid eco-geographical group are distinguished by increased winter hardiness. Among them, Rambler (k-33299) and Rhizoma (k-32785) have properties for the formation of root offspring, and are slightly affected by brown spotting, false-mildew and viral diseases;

(3) Samples from the North Kazakhstan, North American, North Caucasian, Southeastern, Northeastern, Northwestern and Central Russian eco-geographical groups are distinguished by increased winter hardiness. In general, high winter hardiness is characteristic of samples of $M$. varia;

(4) Samples from Mexican-Brazilian, Indian and Chilean-Peruvian eco-geographical groups are a source of rapid growth in spring and after cuttings, but in most cases, they are less winter hardy;

(5) Samples from the Transcaucasian plain eco-geographical group are distinguished by high lining;

(6) Samples from the Plain-Turkestan, Semirechin, South European and North African eco-geographical groups are characterized by higher yields in the Southeast of Kazakhstan.

The investigation results of alfalfa samples confirmed the low productivity of wild species, although they differ in separate valuable features and properties important for breeding. The alfalfa blue ( $M$. coerulea Less.) is distinguished for salt tolerance, $M$. difalcata L. and $M$. falcate L. for drought tolerance, and others are distinguished according to resistance to diseases, almost all species of wild alfalfa. Therefore, wild species are of interest as sources and donors for improving cultivated alfalfa cultivars based on backcross, taking into account the level of ploidy and the transfer of diploid species to the tetraploid level to overcome the non-crosslinking of species, or through the use of genetic engineering techniques [10-12].

From the point of view of population genetics, the use of inbred lines in the creation of synthetics is more effective than heterogeneous parent forms at the level 
of biotypes or individual genotypes. The use of inbred lines involves longer work related to the selection process for homozygous lines with a high overall combinational ability. It is important to establish the optimal level of inbreeding, that is, the generation of inbreeding from which it is advisable to select clones with a high overall combinational ability. For the first time, experimentally, the value of the total combinative ability was established by studying this genetic indicator in the generations $\mathrm{J}_{0}$ and $\mathrm{J}_{1}-\mathrm{J}_{7}$ by the method of topcross on the example of inbred lines from the varieties Semirechenskaya local and Dawson (USA).

As shown in Table 2, the mean squares, which served as the evaluation of the variants of GCA and specific combinational ability (SCA), were significant for all the studied features at $P<0.01$.

The GCA dispersion (or variation) proved to be much higher than SCA, indicating the predominant value of the genes of the additive type of action in the genetic control system for the productivity of green mass, the height and bushiness of the alfalfa lines. For selection of alfalfa, it is important to have data characterizing the overall combinational ability, since the value of this indicator in the initial forms determines the value of synthetic varieties [9-12].

The variance analysis of the indices of $F_{1}$ topcross hybrids made it possible to establish the presence of significant differences between $F_{f}$ and $F_{1}$, which gave grounds for determining the effects of GCA inbred lines as a function of the level of the insulin.

The increase in GCA was observed in all the studied generations of inbreeding at the lines of the second $\left(\mathrm{J}_{2}\right)$ and third $\left(\mathrm{J}_{3}\right)$ generations, which stably showed this property over all six stitches during the two years of testing. The advantage of $\mathrm{J}_{2}$ and $\mathrm{J}_{3}$ was confirmed both by the clone from the Semirechenskaya local variety and Dawson variety.

The oscillation of the effects of GCA in $J_{2}$ (Semirechenskaya local) was depending on the mowing (with a positive value). The variation of $\mathrm{J}_{2}$ of

Table 2 Effects of GCA on the productivity of green mass of lucerne.

\begin{tabular}{|c|c|c|c|c|c|c|c|c|}
\hline \multirow{3}{*}{$\begin{array}{l}\text { Inbreeding } \\
\text { generation }\end{array}$} & \multicolumn{8}{|c|}{ Mean squares } \\
\hline & \multicolumn{3}{|c|}{ First year of life } & \multicolumn{5}{|c|}{ Second year of life } \\
\hline & 1st mowing & 2nd mowing & Average & 1st mowing & 2nd mowing & 3rd mowing & 4th mowing & Average \\
\hline \multicolumn{9}{|c|}{ Lines obtained from Semirechenskaya local variety } \\
\hline$\overline{\mathrm{J}_{0}}$ & -8.28 & -6.71 & -15.01 & -49.28 & -49.00 & -32.17 & -26.43 & -213.53 \\
\hline $\mathrm{J}_{1}$ & 0.28 & -1.60 & -1.35 & 20.72 & -6.33 & 13.94 & 1.54 & 35.58 \\
\hline $\mathrm{J}_{2}$ & 3.72 & 2.07 & 5.76 & 31.28 & 22.11 & 15.94 & 20.68 & 100.03 \\
\hline $\mathrm{J}_{3}$ & 2.94 & 1.96 & 4.99 & 26.39 & 49.44 & 21.94 & 6.13 & 113.92 \\
\hline $\mathrm{J}_{4}$ & 0.94 & 0.85 & 1.76 & 2.06 & 26.33 & -8.28 & 5.79 & 35.92 \\
\hline $\mathrm{J}_{5}$ & 0.28 & 0.74 & 0.99 & -12.94 & -13.89 & 10.50 & 5.90 & -11.53 \\
\hline $\mathrm{J}_{6}$ & 0.94 & 0.63 & 1.54 & 2.50 & -3.78 & -4.94 & 17.68 & 19.47 \\
\hline $\mathrm{J}_{7}$ & -0.83 & 2.07 & 1.32 & -20.72 & -24.89 & -16.94 & -13.32 & -83.86 \\
\hline Mistake & 1.34 & 1.62 & 2.31 & 6.89 & 5.64 & 4.38 & 6.21 & 22.53 \\
\hline \multicolumn{9}{|c|}{ Lines obtained from Dawson variety } \\
\hline$\overline{\mathrm{J}_{0}}$ & -6.65 & -9.81 & -16.18 & -39.29 & -47.21 & -22.28 & -19.69 & -128.53 \\
\hline $\mathrm{J}_{1}$ & -2.99 & -2.03 & -4.74 & -0.07 & -19.32 & 2.17 & 16.64 & -0.64 \\
\hline $\mathrm{J}_{2}$ & 1.46 & 2.75 & 4.49 & 37.15 & 27.13 & 19.72 & 15.86 & 99.81 \\
\hline $\mathrm{J}_{3}$ & 3.68 & 1.86 & 5.82 & 15.93 & 21.35 & 16.83 & 1.97 & 56.03 \\
\hline $\mathrm{J}_{4}$ & -0.87 & 3.19 & 2.60 & 0.82 & 4.24 & -1.94 & -2.69 & 0.36 \\
\hline $\mathrm{J}_{5}$ & 1.24 & 2.97 & 2.26 & 8.15 & 17.79 & 5.06 & 1.97 & 32.92 \\
\hline $\mathrm{J}_{6}$ & 2.79 & 0.64 & 3.71 & -23.62 & -9.43 & -16.61 & -13.69 & -63.42 \\
\hline $\mathrm{J}_{7}$ & 1.35 & 0.42 & 2.04 & 0.93 & 5.46 & -2.94 & -0.36 & 3.47 \\
\hline Mistake & 0.99 & 1.71 & 2.32 & 5.60 & 4.45 & 3.36 & 2.03 & 7.79 \\
\hline
\end{tabular}


Semirechenskaya local in the first year of life was 2.07-3.72 from 1st mowing to 2nd mowing, while in the second year, from 15.94 to 31.28 within the four mowing. In $\mathrm{J}_{3}$, the variation range was $1.96-2.94$ and 6.13-49.44 in mowing, for the first and second year, respectively.

For Dawson line in $\mathrm{J}_{2}$, the effects of GCA varied respectively, from 1.46 to 2.75 and from 15.86 to 37.15 in the first and second year. In $\mathrm{J}_{3}$, the range was, respectively, over the years from 1.86 to 3.68 and from 1.97 to 21.35 .

The GCA effects over the years for the lines in $\mathrm{J}_{2}$ and $\mathrm{J}_{3}$ turned out to be significantly higher in comparison with the indices, not only of $\mathrm{J}_{0}$, but also of $\mathrm{J}_{1}$ and $\mathrm{J}_{4}-\mathrm{J}_{7}$.

Single incision is not always allocated lines with high effects of GCA. With deep inzuht, starting with $\mathrm{J}_{4}$, the lines have a strong inbreeding depression on economically valuable traits and their use in hybridization does not provide high GCA. Thus, the results of a comparative evaluation of the GCA of different generations of inbreeding on the productivity of green mass make it possible to draw an important conclusion that for selection of baselines. It is necessary to select from the splitting of generations of inzuht in $\mathrm{J}_{2}$ and $\mathrm{J}_{3}$ (Table 3).

For alfalfa variety "Kokoray", the elimination method is to select the best plants with a set of economically valuable traits and a general combinative ability. The initial forms were five inbred lines $\left(\mathrm{J}_{2}-132\right.$ from sample K-6940, India; $\mathrm{J}_{2}-101$ from Kapchagayskaya 80; $\mathrm{J}_{3}-53$ from Semirechenskaya local variety; $\mathrm{J}_{2}-212$ from sample K-41340, Italy; 23-4 from variety Omsk 8893) and one heterozygous plant from Omskaya 8893. According to competitive varieties tests for two cycles, the yield of green mass was $64,100 \mathrm{~kg} / \mathrm{ha}, 14,800 \mathrm{~kg} / \mathrm{ha}$ of hay and $349 \mathrm{~kg} / \mathrm{ha}$ of seeds, which exceeded the standard by $22.4 \%, 22.5 \%$ and $28.3 \%$, respectively.

For alfalfa variety "Osimtal", the elimination method is to select the combinational valuable inbred lines by polycross. The variety consists of five inbred lines: 6 D-19/24, D-8/65 from Dawson; C-21/14

Table 3 Characteristics of varieties.

\begin{tabular}{|c|c|c|c|c|}
\hline Variety & Elimination method & $\begin{array}{l}\text { Green mass } \\
(\mathrm{kg} / \mathrm{ha})\end{array}$ & $\begin{array}{l}\text { Hay } \\
(\mathrm{kg} / \mathrm{ha})\end{array}$ & $\begin{array}{l}\text { Seed } \\
(\mathrm{kg} / \mathrm{ha})\end{array}$ \\
\hline Kokorai & $\begin{array}{l}\text { The selection of the best plants for a set of economically valuable } \\
\text { traits and a general combinative ability. The initial forms were } \\
\text { five inbred lines }\left(\mathrm{J}_{2}-132 \text { from sample K-6940, India; } \mathrm{J}_{2}-101 \text { from }\right. \\
\text { Kapchagayskaya } 80 ; \mathrm{J}_{3}-53 \text { from Semirechenskaya local variety; } \\
\mathrm{J}_{2}-212 \text { from sample K-41340, Italy; } 23-4 \text { from variety Omsk } \\
8893) \text { and one heterozygous plant from Omskaya } 8893 \text {. }\end{array}$ & 64,100 & 14,800 & 349 \\
\hline Kokbalausa & $\begin{array}{l}\text { Method of polycross crosses using the experimentally created } \\
\text { seven inbred lines: K14/27 from Kapchagayskaya } 80 \text {; C6/33 } \\
\text { from the Semirechenskaya local variety; D17/09 from Dawson; } \\
\text { I17/54 and I } 20 / 12 \text { from the Iolotanskaya variety } 1763 \text {; P-12/02, } \\
\text { P-14/08 from the Poyton variety. }\end{array}$ & 60,000 & 13,300 & 380 \\
\hline Osimtal & $\begin{array}{l}\text { Method of elimination method is to select the combinational } \\
\text { valuable inbred lines by polycross. The variety consists of five } \\
\text { inbred lines: } 6 \text { D-19/24, D-8/65 from Dawson; C-21/14 from } \\
\text { Semirechenskaya local variety; K-8-41 from Kapchagayskaya } \\
80 ; \mathrm{I}-7 / 3 \text { from Iolotanskaya } 1763 \text {. }\end{array}$ & 68,200 & 14,400 & 270 \\
\hline
\end{tabular}


from Semirechenskaya local variety; K-8-41 from Kapchagayskaya 80; I-7/3 from Iolotanskaya 1763. According to the competitive variety tests for two cycles, the yield of green mass was $60,000 \mathrm{~kg} / \mathrm{ha}$, $13,300 \mathrm{~kg} / \mathrm{ha}$ for hay and $380 \mathrm{~kg} / \mathrm{ha}$ for seed, which exceeded the standard by $25.8 \%, 25.5 \%$ and $18.8 \%$, respectively.

For alfalfa variety "Kukbalausa", the method of elimination is by polycross crosses using the experimentally created seven inbred lines: K14/27 from Kapchagayskaya $80 ; \mathrm{C} 6 / 33$ from the Semirechenskaya local variety; D17/09 from Dawson; I17/54 and I20/12 from the Iolotanskaya variety 1763; P-12/02, P-14/08 from the Poyton variety. According to the competitive variety tests for two cycles, the yield of green mass was $68,200 \mathrm{~kg} / \mathrm{ha}, 14,400 \mathrm{~kg} / \mathrm{ha}$ for hay and $270 \mathrm{~kg} / \mathrm{ha}$ for seeds, which exceeded the standard by $22.0 \%, 21.0 \%$ and $28.5 \%$, respectively.

\section{Conclusions}

In this study, through an extensive collection of alfalfa in the context of species and their eco-geographical groups, the valuable samples for use in breeding have been identified.

Methodical experiments have established the value of incubation up to the generations $\mathrm{J}_{2}$ and $\mathrm{J}_{3}$, where the level of total combinational ability reaches its limit. Further inking does not have a significant effect. It is recommended that the heterosis source material should be translated to the level of the inzuht.

With the use of selection and inbreeding methods in selection of synthetic populations, highly productive alfalfa varieties are created, which are protected by patents: "Kokoray", "Kukbalausa", "Osimtal".

\section{References}

[1] Ivanov, A. I. 1976. "Distribution of Alfafa in Countries and Continents." In Treatise on Botany, Genetics and Breeding. Moscow: Kolos, 151-2.

[2] Meirman, G. T., Yesimbekova, M. A., Yerzhanova, S. T.,
Baytarakova, K. Z., and Mukin, K. B. 2011. Catalog of the Electronic Database of the Collection of Fodder Crops (Genus Medicago, Subgenus Falcago (Reichb) Grossh.).

[3] Meiirman, G. T., and Masonicic-Shotunova, R. 2012. "Genetic Resources and Their Use in Breeding." In Lucerne. Almaty: Asyl Kytap, 47-72.

[4] Meirman, G.T. 2004. "Selection of Alfalfa, Based on the Use of Inbred Lines." Presented at International Scientific Conference on the Strategy of Scientific Support of the Agrarian and Industrial Complex of the Republic of Kazakhstan in the Fields of Agriculture, Plant Growing and Horticulture: Reality and Prospects, Kazakh Agrarian University.

[5] Rotili, P. R., and Zanone, L. 1974. "General and Specific Combining Ability in Lucerne at Different Levels of Inbreeding and Performance of Second Generation Synthetics Measured in Competitive Conditions." $J$. Euphytica 23 (3): 569-77.

[6] Lubenets, P. A., Ivanov, A. I., Kirillov, Y. I., and Kirillov, Y. I. 1979. Methodical Instructions for Studying the Collection of Perennial Forage Grasses. Leningrad: A-RRIPI, 42.

[7] Smurygin, A. F., Novoselova, A.S., Konstantinova, A. M. and Kuleshov, G. F. 1985. "Method for the Selection of Perennial Forage Grasses." In Methodological Instructions for the Selection of Perennial Forage Grasses. Moscow. All-Russian Research Institute of Forages (A-RRIF), 5-48.

[8] Dospechov, B. A. 1985. "One Summer and Perennial Grasses." In Methodology of Field Experience. Moscow: Kolos, 99-103.

[9] Savchenko, V. K. 1973. "Method for Assessing the Combinational Ability of Genetically Different-Quality Sets of Parental Forms." In Methods of Genetic-Selection and Genetic Experiments. Minsk: Science and Technology, 48-77.

[10] Meirman, G. T. 1992. "Effect of the Level of Self-Pollination of the Initial Forms on the GCA of Alfalfa." J. Genetica 28 (1): 81-9.

[11] Meirman, G. T. 1992. "On the Possibility of Assessing the Overall Combinational Ability in Alfalfa by the Method of Topcross on the Basis of Free Pollination." News (Vestnik) of Agricultural Science of Kazakhstan 3 (1): 23-6.

[12] Meirman, G. T., Yerzhanova, S. T., and Baytarakova, K. Z. 2010. Information System of Fodder Crops: Documentation and Study of the Alfalfa Collection. Tashkent: Insitute of Agriculture. 